Article

\title{
New Casbane Diterpenoids from a South China Sea Soft Coral, Sinularia sp.
}

\author{
Jian Yin ${ }^{1, \dagger}$, Min Zhao ${ }^{1, \dagger}$, Minshan Ma ${ }^{2}$, Yuping Xu ${ }^{1}$, Zheng Xiang ${ }^{1}$, Yuepiao Cai ${ }^{1}$, \\ Jianyong Dong ${ }^{1}$, Xinxiang Lei ${ }^{2}$, Kexin Huang ${ }^{1, *}$ and Pengcheng Yan ${ }^{1, *}$ \\ 1 School of Pharmacy, Wenzhou Medical College, Wenzhou 325035, China; \\ E-Mails: yinjian198708@gmail.com (J.Y.); miniezhao@gmail.com (M.Z.); \\ zjxuyuping@gmail.com (Y.X.); xzh007@126.com (Z.X.); ypcai@wzmc.edu.cn (Y.C.); \\ jianyd@wzmc.edu.cn (J.D.) \\ 2 Analytical and Testing Center, Wenzhou University, Wenzhou 325035, China; \\ E-Mails: youihj1023@gmail.com (M.M.); xxlei@wzu.edu.cn (X.L.) \\ $\dagger$ These authors contributed equally to this work. \\ * Authors to whom correspondence should be addressed; E-Mails: hkx@wzmc.edu.cn (K.H.); \\ yanpc@wzmc.edu.cn (P.Y.); Tel./Fax: +86-577-8668-9706 (K.H.); \\ Tel.: +86-577-8669-9229 (P.Y.); Fax: +86-577-8668-9983 (P.Y.).
}

Received: 6 November 2012; in revised form: 15 January 2013 / Accepted: 29 January 2013 /

Published: 6 February 2013

\begin{abstract}
Six new casbane diterpenoids, named as sinularcasbanes A-F (1-6), along with six known analogues 7-12, were isolated from a South China Sea soft coral, Sinularia sp. The structures of the new compounds were elucidated by extensive spectroscopic analysis and by comparison with data reported in the literature. All compounds were evaluated for their cytotoxicity against selected cancer cell lines and the inhibition of lipopolysaccharide (LPS)-induced nitric oxide (NO) production in mouse peritoneal macrophages.
\end{abstract}

Keywords: soft coral; Sinularia; casbane diterpenoids; cytotoxicity; NO inhibition

\section{Introduction}

The casbanes are a small group of diterpenoids strictly related to the cembrane skeleton, and characterized by the presence of a dimethyl-cyclopropyl moiety fused to the 14-membered ring. To date, approximately 33 casbane diterpenoids, in the majority of which the two rings forming the 
macrocyclic structure are cis-fused, have been isolated and described mainly from some plants of the family Euphorbiaceae [1-13], as well as from two species of soft coral belonging to the genus Sinularia (S. microclavata and S. depressa) [14,15]. The biological potential of casbane diterpenoids has not been explored extensively, however some members of this group have been proven to display moderate cytotoxicity and antimicrobial activity $[14,15]$.

Soft corals belonging to the genus Sinularia distribute widely in the tropical reef, and have been shown to be a plentiful source of diterpenoids, possessing a range of biological activities [16,17]. Our recent study of bioactive natural products from a Hainan soft coral, Sinularia sp., resulted in the isolation of six new casbane diterpenoids 1-6, along with six known analogues 7-12 (Figure 1). The compounds isolated were evaluated for their cytotoxicity against selected cancer cell lines and their inhibitory activity against lipopolysaccharide (LPS)-induced nitric oxide (NO) production in mouse peritoneal macrophages $(\operatorname{PEM} \Phi)$. Herein we report the purification, structural elucidation, and bioactivity of these compounds.

Figure 1. Structures of compounds 1-12.

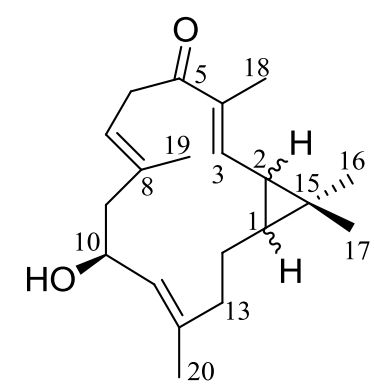

1. $1 \beta-\mathrm{H}, 2 \beta-\mathrm{H}$

8. $1 \alpha-\mathrm{H}, 2 \alpha-\mathrm{H}$

9. $1 \beta-\mathrm{H}, 2 \alpha-\mathrm{H}$

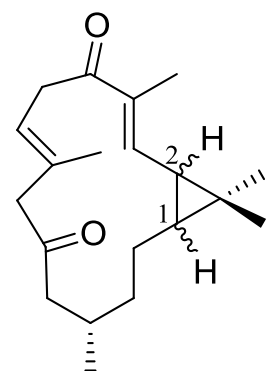

2. $1 \beta-\mathrm{H}, 2 \beta-\mathrm{H}$

10. $1 \alpha-\mathrm{H}, 2 \alpha-\mathrm{H}$

11. $1 \alpha-\mathrm{H}, 2 \beta-\mathrm{H}$

12. $1 \beta-\mathrm{H}, 2 \alpha-\mathrm{H}$

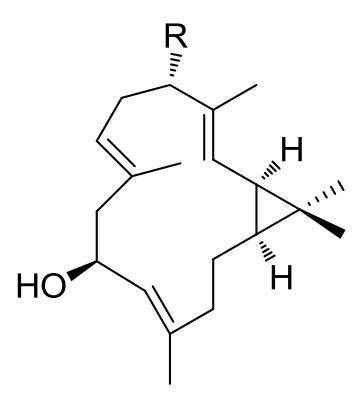

3. $\mathrm{R}=\mathrm{OH}$

4. $\mathrm{R}=\mathrm{H}$

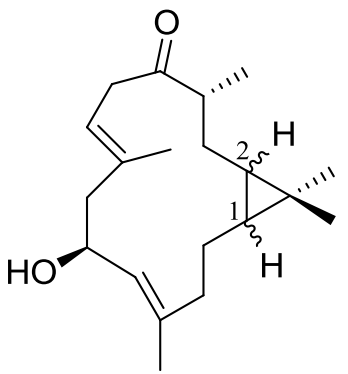

5. $1 \beta-\mathrm{H}, 2 \beta-\mathrm{H}$

6. $1 \beta-H, 2 \alpha-H$

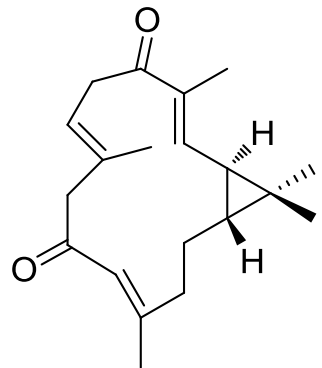

7

\section{Results and Discussion}

Sinularcasbane A (1) had a molecular formula of $\mathrm{C}_{20} \mathrm{H}_{30} \mathrm{O}_{2}$ as determined by HRESIMS $\mathrm{m} / \mathrm{z}$ $325.2142[\mathrm{M}+\mathrm{Na}]^{+}$(Calcd. 325.2138) and NMR data, requiring six degrees of unsaturation. The ${ }^{1} \mathrm{H}$ NMR spectrum of $\mathbf{1}$ showed resonances for five methyl singlets including three olefinic methyls $\left[\delta_{\mathrm{H}} 1.58(3 \mathrm{H}, \mathrm{s}), 1.68(3 \mathrm{H}, \mathrm{s})\right.$, and $\left.1.88(3 \mathrm{H}, \mathrm{s})\right]$ and two tertiary methyls $\left[\delta_{\mathrm{H}} 1.06(3 \mathrm{H}, \mathrm{s}), 1.17(3 \mathrm{H}, \mathrm{s})\right]$, while the ${ }^{13} \mathrm{C}$ NMR spectrum displayed 20 carbon resonances including a carbonyl and six olefinic carbons (Tables 1 and 2). The IR absorption at $1655 \mathrm{~cm}^{-1}$ and ${ }^{13} \mathrm{C}$ NMR signal at $\delta_{\mathrm{C}} 199.8$ (C-5) indicated the presence of an $\alpha, \beta$-unsaturated ketone group. Six olefinic carbon signals in the ${ }^{13} \mathrm{C}$ NMR spectrum at $\delta_{\mathrm{C}} 142.6$ (CH-3), 139.8 (C-12), 137.2 (C-4), 134.1 (C-8), 127.1 (CH-11), and $122.0(\mathrm{CH}-7)$, and three olefinic proton signals in the ${ }^{1} \mathrm{H}$ NMR spectrum at $\delta_{\mathrm{H}} 6.30(1 \mathrm{H}, \mathrm{d}$, $J=10.0 \mathrm{~Hz}, \mathrm{H}-3), 5.09(1 \mathrm{H}$, br d, $J=9.0 \mathrm{~Hz}, \mathrm{H}-7)$, and $4.98(1 \mathrm{H}, \mathrm{d}, J=9.5 \mathrm{~Hz}, \mathrm{H}-11)$ were attributed to three trisubstituted double bonds. In addition, a secondary hydroxyl group was observed from an oxymethine proton signal at $\delta_{\mathrm{H}} 4.53(1 \mathrm{H}, \mathrm{dt}, J=5.0,9.5 \mathrm{~Hz}, \mathrm{H}-10)$ and carbon resonance at $\delta_{\mathrm{C}} 66.2$ (CH-10). Four degrees of unsaturation, accounted for by the functional groups from six in the molecule, suggested a bicyclic structure in 1. Moreover, a dimethyl-cyclopropyl moiety was 
established by HMBC correlations from the two tertiary methyls mentioned above to a quaternary carbon $\left(\delta_{\mathrm{C}} 25.8, \mathrm{C}-15\right)$ and two methine carbons [ $\left.\delta_{\mathrm{C}} 34.6(\mathrm{CH}-1), 27.3(\mathrm{CH}-2)\right]$, in association with COSY correlations between two methine protons $\left[\delta_{\mathrm{H}} 1.14(1 \mathrm{H}, \mathrm{m}, \mathrm{H}-1), 1.51(1 \mathrm{H}, \mathrm{t}, J=9.0 \mathrm{~Hz}, \mathrm{H}-2)\right]$, suggesting a casbane skeleton for 1. Furthermore, detailed 2D NMR data analysis revealed that 1 shared the same gross structure as 10-hydroxydepressin (8) [15]. The difference found in the significantly upfield shifted C-20 ( $\left.\delta_{\mathrm{C}} 15.0\right)$ compared to $8\left(\delta_{\mathrm{C}} 18.3\right)$, implying compound 1 was a diastereomer of $\mathbf{8}$. The $E$ geometry of all three double bonds of 1 was inferred by the chemical shifts of C-18, C-19, and C-20 (<20 ppm) [15]. The junction of the cyclopropyl ring at carbons C-1/C-2 was suggested to be cis based from the diagnostic ${ }^{13} \mathrm{C}$ NMR chemical shifts of C-16 and C-17 $\left(\delta_{\mathrm{C}} 15.9\right.$ and 29.0, respectively), in accordance with those reported for $\mathbf{8}$. On biogenetic considerations, the same relative configuration of $\mathrm{C}-10$ was assumed for $\mathbf{1}$. Consequently, the relative configurations of $\mathrm{C}-1$ and $\mathrm{C}-2$ in $\mathbf{1}$ had to be opposite to those of $\mathbf{8}$ for the diastereomeric relationship. Due to the reversed ring junction, $\mathbf{1}$ was found to have a rotation of positive phase $\left([\alpha]_{\mathrm{D}}^{25}+127.1\right)$ in contrast to that of $\mathbf{8}$.

Table $1 .{ }^{13} \mathrm{C}$ NMR data for compounds $\mathbf{1}-\mathbf{6}\left(\mathrm{CDCl}_{3}, 125 \mathrm{MHz}, \delta_{\mathrm{C}}\right)$.

\begin{tabular}{|c|c|c|c|c|c|c|}
\hline No. & 1 & 2 & 3 & 4 & 5 & 6 \\
\hline 1 & $34.6(\mathrm{CH})$ & $34.8(\mathrm{CH})$ & $31.5(\mathrm{CH})$ & $30.7(\mathrm{CH})$ & $24.4(\mathrm{CH})$ & $28.1(\mathrm{CH})$ \\
\hline 2 & $27.3(\mathrm{CH})$ & $27.6(\mathrm{CH})$ & $25.7(\mathrm{CH})$ & $25.9(\mathrm{CH})$ & $24.6(\mathrm{CH})$ & $24.8(\mathrm{CH})$ \\
\hline 3 & $142.6(\mathrm{CH})$ & $144.0(\mathrm{CH})$ & $125.5(\mathrm{CH})$ & $121.2(\mathrm{CH})$ & $28.5\left(\mathrm{CH}_{2}\right)$ & $30.2\left(\mathrm{CH}_{2}\right)$ \\
\hline 4 & $137.2(\mathrm{C})$ & $135.8(\mathrm{C})$ & $136.9(\mathrm{C})$ & $135.8(\mathrm{C})$ & $43.9(\mathrm{CH})$ & $46.5(\mathrm{CH})$ \\
\hline 5 & $199.8(\mathrm{C})$ & 199.5 (C) & $79.3(\mathrm{CH})$ & $39.4\left(\mathrm{CH}_{2}\right)$ & $214.8(\mathrm{C})$ & $211.9(\mathrm{C})$ \\
\hline 6 & $39.1\left(\mathrm{CH}_{2}\right)$ & $40.3\left(\mathrm{CH}_{2}\right)$ & $33.2\left(\mathrm{CH}_{2}\right)$ & $25.0\left(\mathrm{CH}_{2}\right)$ & $42.8\left(\mathrm{CH}_{2}\right)$ & $40.5\left(\mathrm{CH}_{2}\right)$ \\
\hline 7 & $122.0(\mathrm{CH})$ & $123.6(\mathrm{CH})$ & $121.9(\mathrm{CH})$ & $127.0(\mathrm{CH})$ & $120.3(\mathrm{CH})$ & $120.0(\mathrm{CH})$ \\
\hline 8 & $134.1(\mathrm{C})$ & $129.9(\mathrm{C})$ & $132.5(\mathrm{C})$ & $130.8(\mathrm{C})$ & $136.6(\mathrm{C})$ & $134.5(\mathrm{C})$ \\
\hline 9 & $47.5\left(\mathrm{CH}_{2}\right)$ & $52.2\left(\mathrm{CH}_{2}\right)$ & $47.8\left(\mathrm{CH}_{2}\right)$ & $48.0\left(\mathrm{CH}_{2}\right)$ & $47.5\left(\mathrm{CH}_{2}\right)$ & $47.2\left(\mathrm{CH}_{2}\right)$ \\
\hline 10 & $66.2(\mathrm{CH})$ & $206.8(\mathrm{C})$ & $66.5(\mathrm{CH})$ & $66.9(\mathrm{CH})$ & $66.5(\mathrm{CH})$ & $67.4(\mathrm{CH})$ \\
\hline 11 & $127.1(\mathrm{CH})$ & $47.4\left(\mathrm{CH}_{2}\right)$ & $127.7(\mathrm{CH})$ & $127.0(\mathrm{CH})$ & $126.8(\mathrm{CH})$ & $128.5(\mathrm{CH})$ \\
\hline 12 & $139.8(\mathrm{C})$ & $26.7(\mathrm{CH})$ & $140.1(\mathrm{C})$ & $140.1(\mathrm{C})$ & $140.2(\mathrm{C})$ & $138.6(\mathrm{C})$ \\
\hline 13 & $39.9\left(\mathrm{CH}_{2}\right)$ & $33.9\left(\mathrm{CH}_{2}\right)$ & $40.0\left(\mathrm{CH}_{2}\right)$ & $39.5\left(\mathrm{CH}_{2}\right)$ & $38.0\left(\mathrm{CH}_{2}\right)$ & $40.6\left(\mathrm{CH}_{2}\right)$ \\
\hline 14 & $25.4\left(\mathrm{CH}_{2}\right)$ & $19.7\left(\mathrm{CH}_{2}\right)$ & $24.3\left(\mathrm{CH}_{2}\right)$ & $23.9\left(\mathrm{CH}_{2}\right)$ & $21.1\left(\mathrm{CH}_{2}\right)$ & $24.9\left(\mathrm{CH}_{2}\right)$ \\
\hline 15 & $25.8(\mathrm{C})$ & $25.1(\mathrm{C})$ & $20.7(\mathrm{C})$ & $20.0(\mathrm{C})$ & $17.1(\mathrm{C})$ & $19.6(\mathrm{C})$ \\
\hline 16 & $15.9\left(\mathrm{CH}_{3}\right)$ & $16.0\left(\mathrm{CH}_{3}\right)$ & $28.8\left(\mathrm{CH}_{3}\right)$ & $28.9\left(\mathrm{CH}_{3}\right)$ & $14.9\left(\mathrm{CH}_{3}\right)$ & $21.5\left(\mathrm{CH}_{3}\right)$ \\
\hline 17 & $29.0\left(\mathrm{CH}_{3}\right)$ & $29.1\left(\mathrm{CH}_{3}\right)$ & $15.5\left(\mathrm{CH}_{3}\right)$ & $15.6\left(\mathrm{CH}_{3}\right)$ & $29.2\left(\mathrm{CH}_{3}\right)$ & $22.1\left(\mathrm{CH}_{3}\right)$ \\
\hline 18 & $11.7\left(\mathrm{CH}_{3}\right)$ & $11.3\left(\mathrm{CH}_{3}\right)$ & $10.2\left(\mathrm{CH}_{3}\right)$ & $16.0\left(\mathrm{CH}_{3}\right)$ & $17.3\left(\mathrm{CH}_{3}\right)$ & $13.4\left(\mathrm{CH}_{3}\right)$ \\
\hline 19 & $16.6\left(\mathrm{CH}_{3}\right)$ & $18.6\left(\mathrm{CH}_{3}\right)$ & $17.2\left(\mathrm{CH}_{3}\right)$ & $17.1\left(\mathrm{CH}_{3}\right)$ & $16.9\left(\mathrm{CH}_{3}\right)$ & $17.8\left(\mathrm{CH}_{3}\right)$ \\
\hline 20 & $15.0\left(\mathrm{CH}_{3}\right)$ & $20.2\left(\mathrm{CH}_{3}\right)$ & $18.5\left(\mathrm{CH}_{3}\right)$ & $18.6\left(\mathrm{CH}_{3}\right)$ & $17.2\left(\mathrm{CH}_{3}\right)$ & $16.4\left(\mathrm{CH}_{3}\right)$ \\
\hline
\end{tabular}


Table 2. ${ }^{1} \mathrm{H}$ NMR data for compounds $1-6\left(\mathrm{CDCl}_{3}, 500 \mathrm{MHz}, \delta_{\mathrm{H}}, J\right.$ in $\left.\mathrm{Hz}\right)$.

\begin{tabular}{|c|c|c|c|c|c|c|}
\hline No. & 1 & 2 & 3 & 4 & 5 & 6 \\
\hline 1 & $1.14 \mathrm{~m}$ & $1.02 \mathrm{~m}$ & $0.73 \mathrm{~m}$ & $0.68 \mathrm{~m}$ & $0.19 \mathrm{~m}$ & $0.06 \mathrm{~m}$ \\
\hline 2 & $1.51 \mathrm{t}(9.0)$ & $\begin{array}{c}1.46 \mathrm{dd} \\
(8.0,10.0)\end{array}$ & $1.27 \mathrm{t}(9.0)$ & $1.24 \mathrm{t}(8.5)$ & $0.17 \mathrm{~m}$ & $0.16 \mathrm{~m}$ \\
\hline 3 & $6.30 \mathrm{~d}(10.0)$ & $6.28 \mathrm{~d}(10.0)$ & $5.06 \mathrm{~d}(9.5)$ & $4.86 \mathrm{~d}(9.0)$ & $\begin{array}{l}0.95 \mathrm{~m} \\
1.80 \mathrm{~m}\end{array}$ & $\begin{array}{l}1.60 \mathrm{~m} \\
1.98 \mathrm{~m}\end{array}$ \\
\hline 4 & - & - & - & - & $3.05 \mathrm{~m}$ & $2.70 \mathrm{~m}$ \\
\hline 5 & - & - & $\begin{array}{c}4.03 \mathrm{dd} \\
(4.0,11.0)\end{array}$ & $\begin{array}{l}2.09 \mathrm{~m} \\
2.21 \mathrm{~m}\end{array}$ & - & - \\
\hline \multirow{2}{*}{6} & $\begin{array}{c}2.90 \mathrm{br} \mathrm{d} \\
(14.0)\end{array}$ & $\begin{array}{c}3.00 \mathrm{br} \mathrm{d} \\
(15.0)\end{array}$ & $2.27 \mathrm{~m}$ & $2.07 \mathrm{~m}$ & $\begin{array}{c}3.03 \mathrm{dd} \\
(7.5,15.5)\end{array}$ & $\begin{array}{c}2.76 \mathrm{dd} \\
(6.5,14.5)\end{array}$ \\
\hline & $\begin{array}{c}3.62 \mathrm{dd} \\
(9.0,14.0)\end{array}$ & $\begin{array}{c}3.66 \mathrm{dd} \\
(8.0,15.0)\end{array}$ & $2.38 \mathrm{~m}$ & $2.20 \mathrm{~m}$ & $\begin{array}{c}3.19 \mathrm{dd} \\
(7.5,15.5)\end{array}$ & $\begin{array}{c}3.34 \mathrm{dd} \\
(8.5,14.5)\end{array}$ \\
\hline 7 & 5.09 br d $(9.0)$ & 5.29 br d (8.0) & $4.74 \mathrm{t}(6.5)$ & $4.89 \mathrm{t}(6.0)$ & $5.32 \mathrm{t}(7.5)$ & $5.15 \mathrm{t}(7.0)$ \\
\hline 9 & $\begin{array}{c}2.12 \mathrm{~m} \\
2.46 \mathrm{brd}(12.0)\end{array}$ & $\begin{array}{l}2.93 \mathrm{~d}(18.0) \\
2.95 \mathrm{~d}(18.0)\end{array}$ & $\begin{array}{c}2.10 \mathrm{dd} \\
(11.0,13.5) \\
2.35 \mathrm{~m}\end{array}$ & $\begin{array}{l}2.10 \mathrm{~m} \\
2.37 \mathrm{~m}\end{array}$ & $\begin{array}{c}2.36 \mathrm{dd} \\
(7.5,13.0) \\
2.47 \mathrm{dd} \\
(4.0,13.0)\end{array}$ & $\begin{array}{c}2.10 \mathrm{~m} \\
2.50 \mathrm{br} \mathrm{d} \\
(14.0)\end{array}$ \\
\hline 10 & $4.53 \mathrm{dt}(5.0,9.5)$ & - & $\begin{array}{c}4.52 \mathrm{dt} \\
(2.5,9.0)\end{array}$ & $\begin{array}{c}4.55 \mathrm{dt} \\
(3.5,9.0)\end{array}$ & $\begin{array}{c}4.66 \mathrm{dt} \\
(4.0,8.5)\end{array}$ & $\begin{array}{c}4.69 \mathrm{dt} \\
(3.5,9.0)\end{array}$ \\
\hline 11 & $4.98 \mathrm{~d}(9.5)$ & $\begin{array}{c}2.17 \mathrm{dd} \\
(3.0,18.0) \\
2.59 \mathrm{dd} \\
(10.0,18.0)\end{array}$ & $4.98 \mathrm{~d}(9.0)$ & $5.00 \mathrm{~d}(9.0)$ & $5.37 \mathrm{~d}(8.5)$ & $4.93 \mathrm{~d}(9.0)$ \\
\hline 12 & - & $2.33 \mathrm{~m}$ & - & - & - & - \\
\hline \multirow{2}{*}{13} & $1.80 \mathrm{~m}$ & $1.28 \mathrm{~m}$ & $1.85 \mathrm{~m}$ & $1.83 \mathrm{~m}$ & $2.08 \mathrm{~m}$ & $1.79 \mathrm{~m}$ \\
\hline & $2.23 \mathrm{~m}$ & $1.40 \mathrm{~m}$ & $2.29 \mathrm{~m}$ & $2.27 \mathrm{~m}$ & $2.12 \mathrm{~m}$ & $2.11 \mathrm{~m}$ \\
\hline \multirow{2}{*}{14} & $0.77 \mathrm{~m}$ & $0.97 \mathrm{~m}$ & $1.05 \mathrm{~m}$ & $1.15 \mathrm{~m}$ & $1.23 \mathrm{~m}$ & $1.03 \mathrm{~m}$ \\
\hline & $2.10 \mathrm{~m}$ & $1.43 \mathrm{~m}$ & $1.74 \mathrm{~m}$ & $1.73 \mathrm{~m}$ & $1.72 \mathrm{~m}$ & $1.48 \mathrm{~m}$ \\
\hline 16 & $1.06 \mathrm{~s}$ & $1.10 \mathrm{~s}$ & $1.08 \mathrm{~s}$ & $1.09 \mathrm{~s}$ & $0.87 \mathrm{~s}$ & $0.97 \mathrm{~s}$ \\
\hline 17 & $1.17 \mathrm{~s}$ & $1.15 \mathrm{~s}$ & $0.97 \mathrm{~s}$ & $0.98 \mathrm{~s}$ & $0.96 \mathrm{~s}$ & $1.02 \mathrm{~s}$ \\
\hline 18 & $1.88 \mathrm{~s}$ & $1.81 \mathrm{~s}$ & $1.65 \mathrm{~s}$ & $1.64 \mathrm{~s}$ & $1.07 \mathrm{~d}(7.0)$ & $1.04 \mathrm{~d}(7.0)$ \\
\hline 19 & $1.58 \mathrm{~s}$ & $1.82 \mathrm{~s}$ & $1.63 \mathrm{~s}$ & $1.61 \mathrm{~s}$ & $1.69 \mathrm{~s}$ & $1.74 \mathrm{~s}$ \\
\hline 20 & $1.68 \mathrm{~s}$ & $0.96 \mathrm{~d}(7.0)$ & $1.68 \mathrm{~s}$ & $1.68 \mathrm{~s}$ & $1.78 \mathrm{~s}$ & $1.73 \mathrm{~s}$ \\
\hline
\end{tabular}

The HRESIMS of sinularcasbane B (2) exhibited a pseudomolecular ion peak at $\mathrm{m} / \mathrm{z} 325.2134$ $[\mathrm{M}+\mathrm{Na}]^{+}$, consistent with the molecular formula of $\mathrm{C}_{20} \mathrm{H}_{30} \mathrm{O}_{2}$. Analysis of the ${ }^{1} \mathrm{H}$ and ${ }^{13} \mathrm{C}$ NMR spectra of 2 clearly revealed the presence of two trisubstituted double bonds $\left[\delta_{\mathrm{H}} 6.28(1 \mathrm{H}, \mathrm{d}\right.$, $J=10.0 \mathrm{~Hz}, \mathrm{H}-3), 5.29(1 \mathrm{H}$, br d, $J=8.0 \mathrm{~Hz}, \mathrm{H}-7) ; \delta_{\mathrm{C}} 144.0(\mathrm{CH}-3), 135.8(\mathrm{C}-4), 129.9(\mathrm{C}-8)$, and $123.6(\mathrm{CH}-7)]$, two ketones $\left[\delta_{\mathrm{C}} 206.8(\mathrm{C}-10), 199.5\right.$ (C-5)], and five methyls including two olefinic methyls $\left[\delta_{\mathrm{H}} 1.82\left(3 \mathrm{H}, \mathrm{s}, \mathrm{H}_{3}-19\right), 1.81\left(3 \mathrm{H}, \mathrm{s}, \mathrm{H}_{3}-18\right)\right]$, two tertiary methyls $\left[\delta_{\mathrm{H}} 1.10\left(3 \mathrm{H}, \mathrm{s}, \mathrm{H}_{3}-16\right)\right.$, $\left.1.15\left(3 \mathrm{H}, \mathrm{s}, \mathrm{H}_{3}-17\right)\right]$, and a secondary methyl $\left[\delta_{\mathrm{H}} 0.96\left(3 \mathrm{H}, \mathrm{d}, J=7.0 \mathrm{~Hz}, \mathrm{H}_{3}-20\right)\right]$. Further interpretation of 1D and 2D NMR spectroscopic data confirmed that $\mathbf{2}$ shared the same gross structure as 10-oxo-11,12-dihydrodepressin (10), and its two isomers 2-epi-10-oxo-11,12-dihydrodepressin (11) 
and 1-epi-10-oxo-11,12-dihydrodepressin (12) [15]. The $E$ geometry of two double bonds $\Delta^{3(4)}$ and $\Delta^{7(8)}$, and the cis junction of the cyclopropyl moiety in $\mathbf{2}$ was determined on the basis of similar NMR data in comparison with those of 10. In addition, the ${ }^{13} \mathrm{C}$ NMR chemical shifts of C-11 $\left(\delta_{\mathrm{C}} 47.4\right), \mathrm{C}-13$ $\left(\delta_{\mathrm{C}} 33.9\right), \mathrm{C}-14\left(\delta_{\mathrm{C}} 19.7\right)$, and C-20 $\left(\delta_{\mathrm{C}} 20.2\right)$ were significantly shifted compared to those reported for $10\left(\delta_{\mathrm{C}} 50.1,39.9,24.5\right.$, and 23.1 , respectively), implying $\mathbf{2}$ had to differ from $\mathbf{1 0}$ in the relative configuration of one or two chiral centers. On the other hand, it was found that $\mathbf{2}$ and $\mathbf{1 0}$ had rotations of opposite sign, allowing the assignment of a different ring junction. Thus, $\mathrm{H}-1$ and $\mathrm{H}-2$ in 2 were suggested to be $\beta$-oriented.

Sinularcasbane $\mathrm{C}$ (3) has a molecular formula of $\mathrm{C}_{20} \mathrm{H}_{32} \mathrm{O}_{2}$ as determined by HRESIMS data $\left(m / z 327.2267[\mathrm{M}+\mathrm{Na}]^{+}\right)$, requiring five degrees of unsaturation. The analysis of 1D and 2D NMR spectroscopic data revealed that the gross structure of $\mathbf{3}$ was closely related to 10-hydroxydepressin (8) [15], with the exception that C-5 was linked to a hydroxyl group instead of a ketone in the latter. This was indicated by the presence of an additional oxygenated methine group $\left[\delta_{\mathrm{H}} 4.03(1 \mathrm{H}\right.$, dd, $\left.J=4.0,11.0 \mathrm{~Hz}, \mathrm{H}-5) ; \delta_{\mathrm{C}} 79.3(\mathrm{CH}-5)\right]$, and its proton exhibiting $\mathrm{HMBC}$ correlations to $\mathrm{C}-18\left(\delta_{\mathrm{C}} 10.2\right.$, $\left.\mathrm{CH}_{3}\right), \mathrm{C}-3\left(\delta_{\mathrm{C}} 125.5, \mathrm{CH}\right)$, and $\mathrm{C}-4\left(\delta_{\mathrm{C}} 136.9, \mathrm{C}\right)$, and in turn the correlations of $\mathrm{H}_{3}-18\left(\delta_{\mathrm{H}} 1.65, \mathrm{~s}\right)$ to $\mathrm{C}-5\left(\delta_{\mathrm{C}} 79.3, \mathrm{CH}\right), \mathrm{C}-3$, and $\mathrm{C}-4$. The geometry of three double bonds and stereogenic centers at $\mathrm{C}-1$, $\mathrm{C}-2$, and $\mathrm{C}-10$ was in agreement with those of $\mathbf{8}$ based on the similar NOE relationships and NMR data in association with the chemical constants. The coupling constant $J_{\mathrm{H}-10 / \mathrm{H}-11}$ of 3 was $9.0 \mathrm{~Hz}$, suggesting $\mathrm{H}-10\left(\delta_{\mathrm{H}} 4.52,1 \mathrm{H}, \mathrm{dt}, J=2.5,9.0 \mathrm{~Hz}\right)$ and $\mathrm{H}-11\left(\delta_{\mathrm{H}} 4.98,1 \mathrm{H}, \mathrm{d}, J=9.0 \mathrm{~Hz}\right)$ were oriented in the trans-axial configuration. The obvious NOE correlations of $\mathrm{H}-11 / \mathrm{H}-14 \mathrm{a}\left(\delta_{\mathrm{H}} 1.05, \mathrm{~m}\right), \mathrm{H}-14 \mathrm{a} / \mathrm{H}-3$ $\left(\delta_{\mathrm{H}} 5.06,1 \mathrm{H}, \mathrm{d}, J=9.0 \mathrm{~Hz}\right.$ ), and $\mathrm{H}-3 / \mathrm{H}-5$ led to the assignment of $\mathrm{H}-5 \beta$, while the NOE interactions of $\mathrm{H}_{3}-18 / \mathrm{H}-2\left(\delta_{\mathrm{H}} 1.27,1 \mathrm{H}, \mathrm{t}, J=9.0 \mathrm{~Hz}\right)$ and $\mathrm{H}-2 / \mathrm{H}-1\left(\delta_{\mathrm{H}} 0.73,1 \mathrm{H}, \mathrm{m}\right)$ supported the $\alpha$-orientation of $\mathrm{H}-1$ and H-2 (Figure 2).

Figure 2. NOESY correlations of compounds 1, 3, 5, and $\mathbf{6}$.

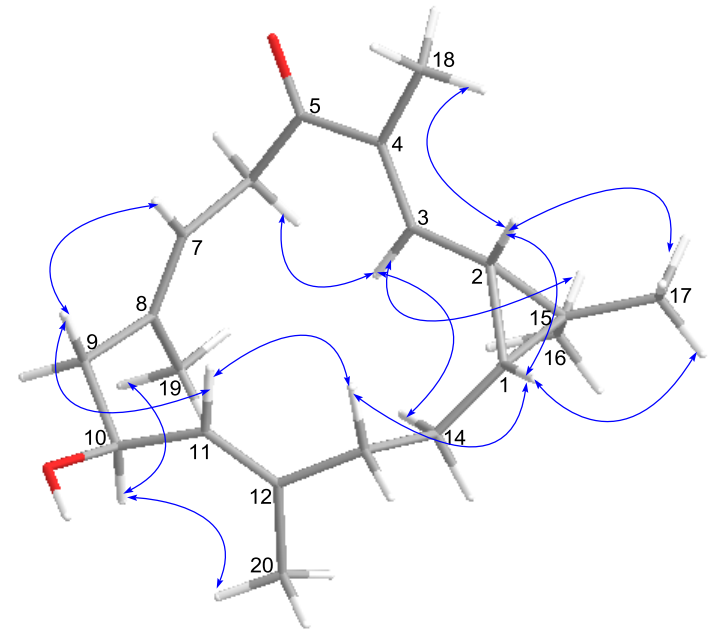

(1)

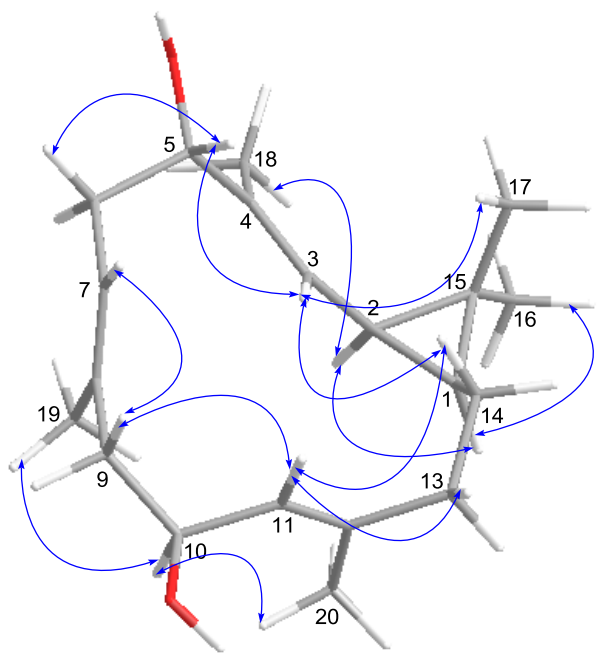

(3) 
Figure 2. Cont.

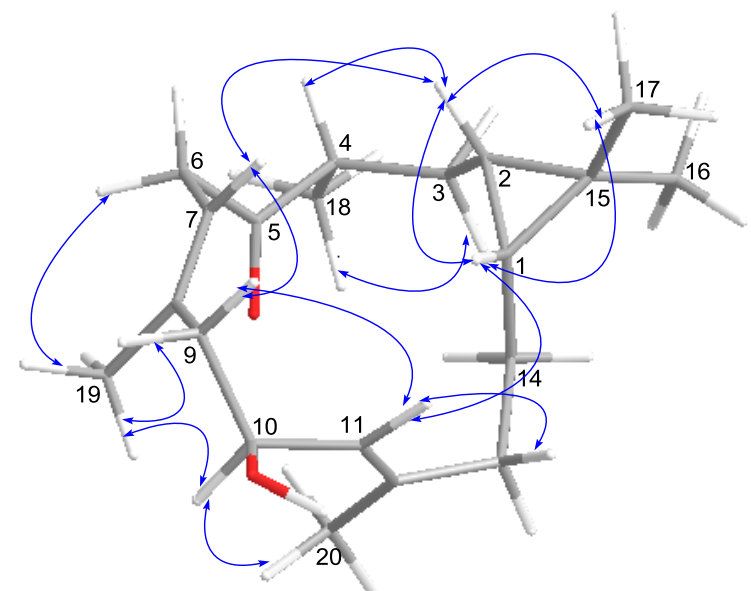

(5)

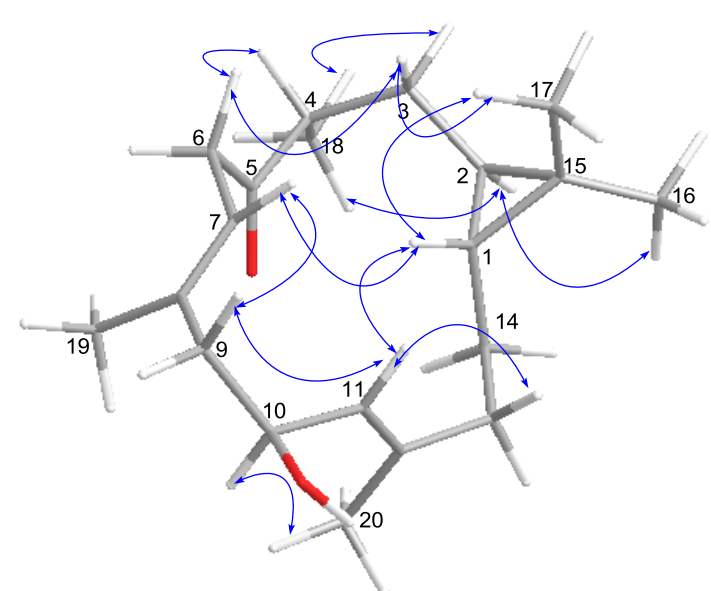

(6)

The NMR spectroscopic data of sinularcasbane D (4) (Tables 1 and 2) indicated that its structure was closely related to that of $\mathbf{3}$. The only difference was found to be the dehydroxylation of C-5 in 4 compared to 3, as evident from the HMBC correlation from $\mathrm{H}_{3}-18\left(\delta_{\mathrm{H}} 1.64, \mathrm{~s}\right)$ to a methylene carbon C-5 $\left(\delta_{\mathrm{C}} 39.4\right)$, instead of a hydroxy-bearing methine carbon $\left(\delta_{\mathrm{C}} 79.3\right)$ as in $\mathbf{3}$. The molecular formula of 4, $\mathrm{C}_{20} \mathrm{H}_{32} \mathrm{O}$ as established by HRESIMS $\left(\mathrm{m} / \mathrm{z} 311.2322[\mathrm{M}+\mathrm{Na}]^{+}\right)$, was $16 \mathrm{amu}$ less than that of 3 and further supported this structure assignment. The relative stereochemistry of 4 was in agreement with that of 3 based on the similar NMR and NOE data. Thus, compound 4 was defined as a C-5 dehydroxylated analogue of $\mathbf{3}$.

The molecular formula of sinularcasbane $\mathrm{E}(5)$ was determined as $\mathrm{C}_{20} \mathrm{H}_{32} \mathrm{O}_{2}$ based on HRESIMS data $\left(\mathrm{m} / z\right.$ 327.2286 $[\mathrm{M}+\mathrm{Na}]^{+}$, Calcd. 327.2295), implying five degrees of unsaturation. The NMR data of $\mathbf{5}$ were compatible with those of $\mathbf{1}$, except for the presence of an additional secondary methyl group $\left[\delta_{\mathrm{H}} 1.07\left(3 \mathrm{H}, \mathrm{d}, J=7.0 \mathrm{~Hz}, \mathrm{H}_{3}-18\right) ; \delta_{\mathrm{C}} 17.3\left(\mathrm{CH}_{3}-18\right)\right]$. The secondary methyl group was assigned to $\mathrm{C}-4$ as evident from $\mathrm{HMBC}$ correlations of its protons $\mathrm{H}_{3}-18$ to ketone carbon $\mathrm{C}-5$ $\left(\delta_{\mathrm{C}} 214.8, \mathrm{C}\right)$, methylene carbon $\mathrm{C}-3\left(\delta_{\mathrm{C}} 28.5, \mathrm{CH}_{2}\right)$, and methine carbon $\mathrm{C}-4\left(\delta_{\mathrm{C}} 43.9, \mathrm{CH}\right)$, in association with the COSY correlations between $\mathrm{H}_{3}-18 / \mathrm{H}-4\left(\delta_{\mathrm{H}} 3.05,1 \mathrm{H}, \mathrm{m}\right), \mathrm{H}-4 / \mathrm{H}_{2}-3\left(\delta_{\mathrm{H}} 0.95,1 \mathrm{H}\right.$, $\mathrm{m} ; 1.80,1 \mathrm{H}, \mathrm{m})$, and $\mathrm{H}_{2}-3 / \mathrm{H}-2\left(\delta_{\mathrm{H}} 0.17,1 \mathrm{H}, \mathrm{m}\right)$. In addition, the remaining substructures from C-6 to $\mathrm{C}-14$ together with the cyclopropyl moiety were confirmed to resemble those of $\mathbf{1}$ by HMBC and COSY correlations as shown in Figure 3. The NOE relationships between $\mathrm{H}-10\left(\delta_{\mathrm{H}} 4.66\right.$, dt, $J=4.0,8.5 \mathrm{~Hz}) / \mathrm{H}_{3}-20\left(\delta_{\mathrm{H}} 1.78, \mathrm{~s}\right)$, and $\mathrm{H}-10 / \mathrm{H}_{3}-19\left(\delta_{\mathrm{H}} 1.69, \mathrm{~s}\right)$ indicated these protons approximated spatially and oriented in the same face, whereas the key NOE interactions between $\mathrm{H}-7\left(\delta_{\mathrm{H}} 5.32\right.$, $\mathrm{t}$, $J=7.5 \mathrm{~Hz}) / \mathrm{H}-2, \mathrm{H}-11\left(\delta_{\mathrm{H}} 5.37, \mathrm{~d}, J=8.5 \mathrm{~Hz}\right) / \mathrm{H}-1\left(\delta_{\mathrm{H}} 0.19, \mathrm{~m}\right), \mathrm{H}-1 / \mathrm{H}-2$, and $\mathrm{H}-2 / \mathrm{H}-4$ supported the $\beta$-orientation of $\mathrm{H}-1, \mathrm{H}-2$ and $\mathrm{H}-4$. 
Figure 3. COSY and HMBC correlations of compounds 1-3 and 5.

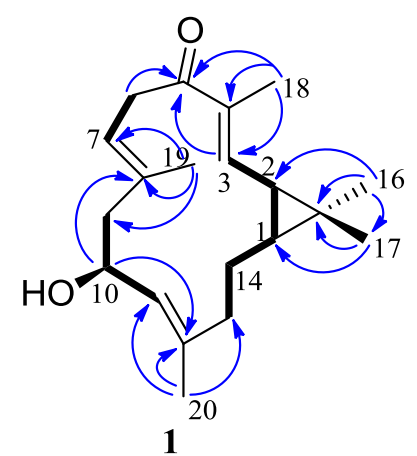

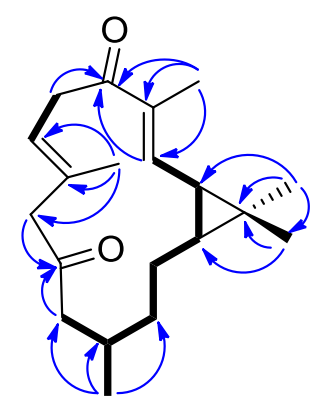

2

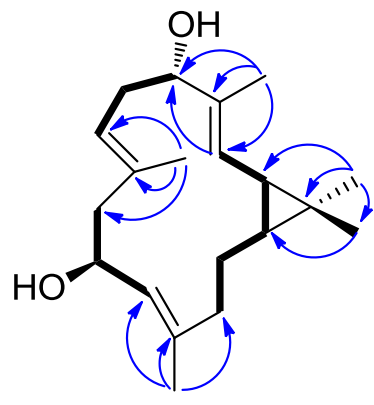

3

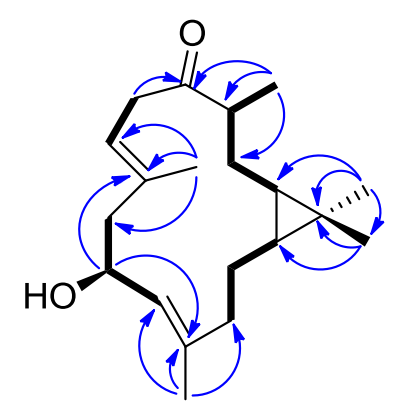

5

- : ${ }^{1} \mathrm{H}-{ }^{1} \mathrm{H}$ COSY correlations

$\curvearrowright$ : HMBC correlations

Sinularcasbane F (6) had the same molecular formula as that of $\mathbf{5}$, as determined by HRESIMS and NMR data (Tables 1 and 2). It was determined to be a stereoisomer of $\mathbf{5}$ based on the extensive 2D NMR spectroscopic analysis and by comparison of its NMR data with those of $\mathbf{5}$. The difference was found in the ${ }^{13} \mathrm{C}$ NMR values of $\mathrm{C}-16\left(\delta_{\mathrm{C}} 21.5, \mathrm{CH}_{3}\right)$ and $\mathrm{C}-17\left(\delta_{\mathrm{C}} 22.1, \mathrm{CH}_{3}\right)$ that were significantly shifted in comparison with those of $\mathbf{5}$, suggesting $\mathbf{6}$ had a different ring junction at carbons $\mathrm{C}-1 / \mathrm{C}-2$. This assignment was further confirmed by the presence of NOE cross-peaks between $\mathrm{H}-1\left(\delta_{\mathrm{H}} 0.06, \mathrm{~m}\right)$ and $\mathrm{H}_{3}-17\left(\delta_{\mathrm{H}} 1.02, \mathrm{~s}\right)$, and between $\mathrm{H}-2\left(\delta_{\mathrm{H}} 0.16, \mathrm{~m}\right)$ and $\mathrm{H}_{3}-16\left(\delta_{\mathrm{H}} 0.97, \mathrm{~s}\right)$, consistent with a trans ring junction. In addition, the NOE correlations of $\mathrm{H}-10\left(\delta_{\mathrm{H}} 4.69\right.$, dt, $J=3.5,10.0 \mathrm{~Hz}) / \mathrm{H}_{3}-20\left(\delta_{\mathrm{H}} 1.73, \mathrm{~s}\right)$ and $\mathrm{H}-11\left(\delta_{\mathrm{H}} 4.93, \mathrm{~d}, J=9.0 \mathrm{~Hz}\right) / \mathrm{H}-1$ indicated the $\beta$-orientation of $\mathrm{H}-1$, while the NOE relationship between $\mathrm{H}-2$ and $\mathrm{H}_{3}-18\left(\delta_{\mathrm{H}} 1.04, \mathrm{~d}, J=7.0 \mathrm{~Hz}\right)$ suggested both $\mathrm{H}-2$ and $\mathrm{H}_{3}-18$ to be $\alpha$-oriented.

The identities of compounds 7-12 were established by comparison of their spectral data with those of the known compounds isolated from $S$. depressa [15]. They are 1-epi-10-oxodepressin (7), 10-hydroxydepressin (8), 1-epi-10-hydroxydepressin (9), 10-oxo-11,12-dihydrodepressin (10), 2-epi-10-oxo-11,12-dihydrodepressin (11), and 1-epi-10-oxo-11,12-dihydrodepressin (12).

Compounds 1-12 were tested for their cytotoxicity against a panel of tumor cell lines including SGC7901 (human gastric carcinoma), A549 (human lung epithelial carcinoma), MCF7 (human breast carcinoma), HCT116 (human colonic carcinoma), B16 (mouse melanoma) and P815 (mouse lymphoblast-like mastocytoma). However, they showed no cytotoxic activity against all cell lines at $50 \mu \mathrm{M}$. In order to detect the anti-inflammatory property of these compounds, the test for inhibition of lipopolysaccharide (LPS)-induced nitric oxide (NO) production in mouse peritoneal macrophages $(\operatorname{PEM} \Phi)$ was performed. The bioassay results revealed compounds $\mathbf{2}$ and $\mathbf{5}$ showed moderate inhibition with an inhibitory concentration $50 \%\left(\mathrm{IC}_{50}\right)$ of 8.3 and $5.4 \mu \mathrm{M}$, respectively, whereas the other compounds showed weak activity $\left(\mathrm{IC}_{50}>10 \mu \mathrm{M}\right)$. In addition, all compounds were weakly cytotoxic toward mouse $\operatorname{PEM} \Phi\left(\mathrm{IC}_{50}>10 \mu \mathrm{M}\right)$. 


\section{Experimental Section}

\subsection{General Experimental Procedures}

Optical rotations were measured on a PoLAAR 3005 digital polarimeter. IR spectra were determined on a Bruker Equinox 55 spectrometer. ${ }^{1} \mathrm{H}$ and ${ }^{13} \mathrm{C}$ NMR and $2 \mathrm{D}$ NMR were recorded on a Bruker Avance $500 \mathrm{MHz}$ NMR spectrometer using TMS as an internal standard. $\delta$ values were expressed in parts per million (ppm), and $J$ values were reported in Hertz (Hz). HRESIMS data were obtained from a Bruker micrO TOF-QII instrument. Silica gel (200-300 mesh) for column chromatography and $\mathrm{GF}_{254}$ silica gel for TLC was provided by Qingdao Marine Chemistry Co. Ltd. Reversed-phase HPLC chromatography was performed on an Agilent 1100 series instrument using a VWD G1314A detector at $210 \mathrm{~nm}$ and a YMC-Pack $\mathrm{C}_{18}(10 \mu \mathrm{m}, 250 \times 10 \mathrm{~mm})$ column.

\subsection{Animal Material}

The soft coral Sinularia sp. was collected off the coast of Ximao island, Hainan Province, China, in November 2011, at a depth of $8 \mathrm{~m}$ and was frozen immediately after collection. The specimen was identified by Xiu-Bao Li (South China Sea Institute of Oceanology, CAS, Guangzhou, China). A voucher specimen (HS201101) is deposited at the Institute of Natural Drugs Development, Wenzhou Medical College, China.

\subsection{Extraction and Isolation}

The frozen soft coral Sinularia sp. $(2.7 \mathrm{~kg})$ was homogenized and then extracted with $95 \% \mathrm{EtOH}$ $(4 \times 3 \mathrm{~L})$ at room temperature. The EtOH extract $(171.5 \mathrm{~g})$ was partitioned between $\mathrm{H}_{2} \mathrm{O}$ and EtOAc. The EtOAc fraction (40.0 g) was subjected to silica gel (200-300 mesh) column chromatography, and was eluted with a gradient of petroleum ether (PE)/EtOAc $(20: 1,10: 1,5: 1,1: 1)$ to obtain nine fractions (F1-F9). F5 (2.7 g) was fractioned on Sephadex LH-20 $\left(70 \times 2.5 \mathrm{~cm}\right.$, eluted with $\left.\mathrm{CH}_{2} \mathrm{Cl}_{2} / \mathrm{MeOH} 1: 1\right)$, and further fractioned on an ODS column $\left(\mathrm{C}_{18}, 25 \times 2 \mathrm{~cm}\right)$, eluted with a gradient of $\mathrm{MeOH} / \mathrm{H}_{2} \mathrm{O}$ (70:30-100:0) to afford seven subfractions (F4A-F4G). The subfraction F4A (62 mg) was further separated on reversed-phase semi-preparative HPLC with $\mathrm{MeOH} / \mathrm{H}_{2} \mathrm{O}(75: 25)$ as a mobile phase to obtain $11(10.0 \mathrm{mg})$. F4D (108 mg) was purified by HPLC $\left(\mathrm{MeOH} / \mathrm{H}_{2} \mathrm{O}, 80: 20\right)$ to afford $7(3.7 \mathrm{mg})$, $2(6.8 \mathrm{mg}), \mathbf{1 2}(10.7 \mathrm{mg})$, and $\mathbf{1 0}(7.9 \mathrm{mg})$. F4G $(53 \mathrm{mg})$ was purified by $\mathrm{HPLC}\left(\mathrm{MeOH} / \mathrm{H}_{2} \mathrm{O}, 90: 10\right)$ to afford $4(9.0 \mathrm{mg})$. F6 $(0.7 \mathrm{~g})$ was subjected to Sephadex LH-20 column eluting with $\mathrm{CH}_{2} \mathrm{Cl}_{2} / \mathrm{MeOH}$ $(1: 1)$ to afford six subfractions (F6A-F6F). The subfraction F6D (99 mg) was purified by HPLC $\left(\mathrm{MeOH} / \mathrm{H}_{2} \mathrm{O}, 80: 20\right)$ to afford $5(14.8 \mathrm{mg})$ and $6(19.0 \mathrm{mg})$. F7 (1.6 g) was subjected to Sephadex LH $20\left(70 \times 2.5 \mathrm{~cm}\right.$, eluted with $\left.\mathrm{CH}_{2} \mathrm{Cl}_{2} / \mathrm{MeOH} 1: 1\right)$, and further separated on an ODS column $\left(\mathrm{C}_{18}\right.$, $25 \times 2 \mathrm{~cm})$, eluted with a gradient of $\mathrm{MeOH} / \mathrm{H}_{2} \mathrm{O}(75: 25-100: 0)$ to furnish five subfractions (F7A-F7E). The subfraction F7C (29 mg) was purified by HPLC (MeOH/ $\left.\mathrm{H}_{2} \mathrm{O}, 80: 20\right)$ to afford $3(10.0 \mathrm{mg})$, while compounds $1(2.1 \mathrm{mg}), \mathbf{8}(25.2 \mathrm{mg})$, and $\mathbf{9}(46.3 \mathrm{mg})$ were obtained from F7D (114 $\mathrm{mg}$ ) by the same separation process as that for F7C. 
Sinularcasbane A (1), obtained as colorless oil; $[\alpha]_{\mathrm{D}}^{25}+127.1\left(\right.$ c $\left.0.21, \mathrm{CHCl}_{3}\right)$; IR $(\mathrm{KBr}) v_{\max } 3434$, 2926, 2859, 1655, 1448, 1384, 1274, 1070, $1017 \mathrm{~cm}^{-1} ;{ }^{1} \mathrm{H}$ and ${ }^{13} \mathrm{C}$ NMR data, see Tables 1 and 2; HRESIMS $(m / z) 325.2142[\mathrm{M}+\mathrm{Na}]^{+}$(Calcd. for $\mathrm{C}_{20} \mathrm{H}_{30} \mathrm{O}_{2} \mathrm{Na}, 325.2138$ ).

Sinularcasbane B (2), obtained as colorless oil; $[\alpha]_{\mathrm{D}}^{25}-29.0\left(\right.$ c $\left.0.60, \mathrm{CHCl}_{3}\right)$; IR ( $\left.\mathrm{KBr}\right) v_{\max } 2927$, 2863, 1708, 1627, 1457, 1376, 1278, 1112, $1061 \mathrm{~cm}^{-1} ;{ }^{1} \mathrm{H}$ and ${ }^{13} \mathrm{C}$ NMR data, see Tables 1 and 2; HRESIMS $(m / z) 325.2134[\mathrm{M}+\mathrm{Na}]^{+}$(Calcd. for $\left.\mathrm{C}_{20} \mathrm{H}_{30} \mathrm{O}_{2} \mathrm{Na}, 325.2138\right)$.

Sinularcasbane C (3), obtained as colorless oil; $[\alpha]_{\mathrm{D}}^{25}-247.6\left(c 0.24, \mathrm{CHCl}_{3}\right)$; IR ( $\left.\mathrm{KBr}\right) v_{\max } 3262$, 2923, 2856, 1445, 1384, $1003 \mathrm{~cm}^{-1} ;{ }^{1} \mathrm{H}$ and ${ }^{13} \mathrm{C}$ NMR data, see Tables 1 and 2; HRESIMS $(\mathrm{m} / z)$ 327.2267 [M $+\mathrm{Na}]^{+}$(Calcd. for $\mathrm{C}_{20} \mathrm{H}_{32} \mathrm{O}_{2} \mathrm{Na}, 327.2295$ ).

Sinularcasbane D (4), obtained as colorless oil; $[\alpha]_{\mathrm{D}}^{25}-127.6\left(c 0.20, \mathrm{CHCl}_{3}\right)$; IR (KBr) $v_{\max } 3435$, 2927, 2860, 1451, 1378, $1378 \mathrm{~cm}^{-1} ;{ }^{1} \mathrm{H}$ and ${ }^{13} \mathrm{C}$ NMR data, see Tables 1 and 2; HRESIMS $(\mathrm{m} / z)$ $311.2322[\mathrm{M}+\mathrm{Na}]^{+}$(Calcd. for $\mathrm{C}_{20} \mathrm{H}_{32} \mathrm{ONa}, 311.2345$ ).

Sinularcasbane E (5), obtained as colorless oil; $[\alpha]_{\mathrm{D}}^{25}+171.8\left(\right.$ c $\left.0.30, \mathrm{CHCl}_{3}\right)$; IR $(\mathrm{KBr}) v_{\max } 3434$, 2927, 2860, 1704, 1453, 1379, $1014 \mathrm{~cm}^{-1}$; ${ }^{1} \mathrm{H}$ and ${ }^{13} \mathrm{C}$ NMR data, see Tables 1 and 2; HRESIMS $(\mathrm{m} / \mathrm{z})$ 327.2286 [M+Na $]^{+}$(Calcd. for $\mathrm{C}_{20} \mathrm{H}_{32} \mathrm{O}_{2} \mathrm{Na}, 327.2295$ ).

Sinularcasbane F (6), obtained as colorless oil; $[\alpha]_{\mathrm{D}}^{25}-166.7\left(c 0.35, \mathrm{CHCl}_{3}\right)$; IR ( $\left.\mathrm{KBr}\right) v_{\max } 3445$, 2927, 2860, 1707, 1626, 1455, 1379, $1043 \mathrm{~cm}^{-1} ;{ }^{1} \mathrm{H}$ and ${ }^{13} \mathrm{C}$ NMR data, see Tables 1 and 2; HRESIMS $(\mathrm{m} / \mathrm{z}) 327.2288[\mathrm{M}+\mathrm{Na}]^{+}$(Calcd. for $\left.\mathrm{C}_{20} \mathrm{H}_{32} \mathrm{O}_{2} \mathrm{Na}, 327.2295\right)$.

\subsection{Cytotoxicity Assay}

The cytotoxicity properties of the isolated compounds were tested in vitro using human tumor cell lines including SGC7901 (human gastric carcinoma), A549 (human lung epithelial carcinoma), MCF7 (human breast carcinoma), HCT116 (human colonic carcinoma), B16 (mouse melanoma) and P815 (mouse lymphoblast-like mastocytoma) tumor cells by a modification of the MTT colorimetric method according to a previously described procedure [18,19]. The cell lines were purchased from the Cell Resource Center of Shanghai Institute of Biological Sciences, CAS.

\subsection{Assay for Inhibition of Nitric Oxide (NO) Production and Cytotoxicity against Mouse Peritoneal Macrophages (PEMФ)}

Dexamethasone (DEX, positive control, $20 \mathrm{mM}$ in DMSO) and each compound (20 mM in DMSO) were diluted to $1-20 \mu \mathrm{M}$ range at r.t. before the experiment. The final percentage of DMSO in the reaction mixture was less than $0.5 \%(\mathrm{v} / \mathrm{v})$. LPS $(1 \mu \mathrm{g} / \mathrm{mL}), 4 \%$ sodium thioglycollate, RPMI1640, fetal bovine serum (FBS), phosphate buffered saline (PBS), MTT and Griess reagents were purchased from Sigma (St, Louis, MO, USA). Mouse peritoneal macrophages (PEM $\Phi$ ) were obtained from C57BL6J male mice, and then plated onto 48 well plates and cultured for $2 \mathrm{~h}$ in Dulbecco's modified Eagle's medium (DMEM) containing 5\% FBS at $5 \% \mathrm{CO}_{2}$ at $37{ }^{\circ} \mathrm{C}$. Mouse PEM $\Phi$ were incubated with the test compounds for $1 \mathrm{~h}$ at $37^{\circ} \mathrm{C}$ before stimulation with $1 \mu \mathrm{g} / \mathrm{mL}$ of lipopolysaccharide (LPS) for $24 \mathrm{~h}$. In the primary test, blank control (enchylema) and LPS were added with the compound $(1 \mu \mathrm{M})$, and DEX $(1 \mu \mathrm{M})$ was prepared. Cells $\left(5 \times 10^{5}\right.$ cells $)$ were preincubated at $37^{\circ} \mathrm{C}$ for $24 \mathrm{~h}$ in serum-free medium, 
and NO production was monitored by measuring nitrite levels in culture media using Griess reagent. Absorbance was measured at $548 \mathrm{~nm}$ in incubated media with Griess reagent for $10 \mathrm{~min}$. Viable adherent cells were stained with MTT $(2 \mu \mathrm{g} / \mathrm{mL})$ for $4 \mathrm{~h}$. Media was then removed and the formazan crystals produced were dissolved in DMSO $(200 \mu \mathrm{L})$. Absorbance was tested at $540 \mathrm{~nm}$. The cytotoxicity against $\operatorname{PEM} \Phi$ was tested by MTT colorimetry [18].

One-way analysis of variance was applied for all statistical analysis by independent experiments, and data were represented as means \pm standard error of the measurement. Individual values were compared by $t$-test and a $p$-value $<0.01$ to evaluate the significance.

\section{Conclusions}

Sinularcasbanes A-F (1-6) together with six known casbane diterpenoids 7-12 were isolated from the EtOAc extract of the South China Sea soft coral Sinularia sp. All of the compounds exhibited no cytotoxic activity against SGC7901, A549, MCF7, HCT116, B16, and P815 tumor cells at $50 \mu \mathrm{M}$ in the in vitro cytotoxicity assay. Sinularcasbanes B (2) and E (5) were found to show moderate inhibitory activity against lipopolysaccharide (LPS)-induced nitric oxide (NO) production in mouse peritoneal macrophages $(\mathrm{PEM} \Phi)$ with an $\mathrm{IC}_{50}$ of 8.3 and $5.4 \mu \mathrm{M}$, respectively. NO plays an important role in the inflammatory process, therefore, sinularcasbanes B (2) and E (5) could be promising lead compounds for anti-inflammatory agents. Other studies should be performed to elucidate the mechanism by which these compounds inhibit the production of NO. A literature survey revealed that sinularcasbanes $\mathrm{E}(\mathbf{5})$ and $\mathrm{F}(\mathbf{6})$ are the first members of the casbane family with a carbon-carbon single bond between carbons $\mathrm{C} 3$ and $\mathrm{C} 4$. The present work provided a group of new casbane diterpenoids with which to enrich the chemical diversity of Sinularia corals.

\section{Acknowledgments}

This research was supported by grant from the NSFC (No. 21202123) and Start-Up Funding from Wenzhou Medical College (No. QTJ10018).

\section{References}

1. Robinson, D.R.; West, C.A. Biosynthesis of cyclic diterpenes in extracts from seedlings of Ricinus communis L. I. Identification of diterpene hydrocarbons formed from mevalonate. Biochemistry 1970, 9, 70-79.

2. Burke, B.A.; Chan, W.R.; Pascoe, K.O.; Biount, J.F.; Manchand, P.S. The structure of crotonitenone, a novel casbane diterpene from Croton nitens Sw. J. Chem. Soc. Perkin Trans. 1 1981, 10, 2666-2669.

3. Commissiong, M.A.; Pascoe, K.O. The absolute stereochemistry of crotonitenone. Tetrahedron Lett. 1984, 25, 711-712.

4. Choi, Y.H.; Kim, J.; Pezzuto, J.M.; Kinghorn, A.D.; Farnsworth, N.R. Agrostistachin, a novel cytotoxic macrocyclic diterpene from Agrostistachys hookeri. Tetrahedron Lett. 1986, 27, 5795-5798. 
5. Choi, Y.H.; Pezzuto, J.M.; Kinghorn, A.D.; Farnsworth, N.R. Plant anticancer agents, XLVI. Cytotoxic casbane-type constituents of Agrostistachys hookeri. J. Nat. Prod. 1988, 51, 110-116.

6. Moura, V.L.A.; Monte, F.J.O.; Braz-Filho, R. A new casbane-type diterpenoid from Croton nepetaefolius. J. Nat. Prod. 1990, 53, 1566-1571.

7. Kashman, Y.; Bernart, M.W.; Tischler, M.; Cardellina, J.H., II; Boyd, M.R. Koumbalones A and B, new casbane diterpenes from Maprounea africana. J. Nat. Prod. 1994, 57, 426-430.

8. Hao, C.; Zhong, J.J. Diterpenes and sesquiterpene from two Euphorbia species-structure elucidation of Euphorhylonal A and Euphoranin E. Indian J. Chem. 1996, 35, 1308-1310.

9. Xu, Z.H.; Sun, J.; Xu, R.S.; Qin, G.W. Casbane diterpenoids from Euphorbia ebracteolata. Phytochemistry 1998, 49, 149-151.

10. Kong, L.Y.; Li, Y.; Wu, X.L.; Min, Z.D. Cytotoxic diterpenoids from Euphorbia pekinensis. Planta Med. 2002, 68, 249-252.

11. Liang, Q.L.; Dai, C.C.; Jiang, J.H.; Tang, Y.P.; Duan, J.A. A new cytotoxic casbane diterpene from Euphorbia pekinensis. Fitoterapia 2009, 80, 514-516.

12. Silva-Filho, F.A.; Braz-Filho, R.; Silveira, E.R.; Lima, M.A.S. Structure elucidation of casbane diterpenes from Croton argyrophyllus. Magn. Reson. Chem. 2011, 49, 370-373.

13. Shao, F.G.; Bu, R.; Zhang, C.; Chen, C.J.; Huang, J.; Wang, J.H. Two new casbane diterpenoids from the roots of Euphorbia pekinensis. J. Asian Nat. Prod. Res. 2011, 13, 805-810.

14. Zhang, C.X.; Yan, S.J.; Zhang, G.W.; Lu, W.G.; Su, J.Y.; Zeng, L.M.; Gu, L.Q.; Yang, X.P.; Lian, Y.J. Cytotoxic diterpenoids from the soft coral Sinularia microclavata. J. Nat. Prod. 2005, 68, 1087-1089.

15. Li, Y.; Carbone, M.; Vitale, R.M.; Amodeo, P.; Castelluccio, F.; Sicilia, G.; Mollo, E.; Nappo, M.; Cimino, G.; Guo, Y.W.; Gavagnin, M. Rare casbane diterpenoids from the Hainan soft coral Sinularia depressa. J. Nat. Prod. 2010, 73, 133-138.

16. Lakshmi, V.; Kumar, R. Metabolites from Sinularia species. Nat. Prod. Res. 2009, 23, 801-850.

17. Li, Y.; Pattenden, G. Novel macrocyclic and polycyclic norcembranoid diterpenes from Sinularia species of soft coral: Structural relationships and biosynthetic speculations. Nat. Prod. Rep. 2011, 28, 429-440.

18. Geran, R.I.; Greenberg, N.H.; MacDonald, M.M.; Schumacher, A.M.; Abbott, B.J. Protocols for screening chemical agents and natural products against animal tumors and other biological syatems. Cancer Chemother. Rep. 1972, 3, 1-91.

19. Hou, R.-S.; Duh, C.-Y; Chiang, M.Y.; Lin, C.-N. Sinugibberol, a new cytotoxic cembranoid diterpene from the soft coral Sinularia gibberosa. J. Nat. Prod. 1995, 58, 1126-1130.

Samples Availability: Available from the authors.

(C) 2013 by the authors; licensee MDPI, Basel, Switzerland. This article is an open access article distributed under the terms and conditions of the Creative Commons Attribution license (http://creativecommons.org/licenses/by/3.0/). 